\title{
Kompetensi Profesional dan Pedagogik Guru Dalam Pengelolaan Pembelajaran di Sekolah Dasar
}

\author{
Saraya Faridah ${ }^{1}$, Ery Tri Djatmika ${ }^{2}$, Sugeng Utaya ${ }^{3}$ \\ ${ }^{1}$ Pendidikan Dasar-Universitas Negeri Malang \\ ${ }^{2}$ Manajemen-Universitas Negeri Malang \\ ${ }^{3}$ Pendidikan Geografi-Universitas Negeri Malang
}

\section{INFO ARTIKEL}

\section{Riwayat Artikel:}

Diterima: 03-07-2019

Disetujui: 25-09-2020

Kata kunci:
professional competence;
pedagogic;
learning management;
kompetensi profesional;
pedagogik;
pengelolaan pembelajaran

\author{
Alamat Korespondensi: \\ Saraya Faridah \\ Pendidikan Dasar \\ Universitas Negeri Malang \\ Jalan Semarang 5 Malang \\ E-mail: sarayafaridah@gmail.com
}

\begin{abstract}
This study aims to study teacher competencies in managing learning, teacher professional strategies and learning in improving education quality. Descriptive research method with qualitative research. Data collection techniques are carried out through interviews, observation, and documentation studies. Based on the results of the study concluded from professional competence and pedagogical knowledge the teacher shows: (1) competencies needed by teachers in learning in preparing lesson plans, preparation of syllabus, planning media and learning resources accompanied by learning in accordance with the instructions provided, but there are some teachers who teach not make learning planning; (2) the teacher's professional strategy in implementing learning, namely: mastering the material, structure, and concepts of the lessons being taught. This is done by reviewing the material before completion, adjusting the material with the media/learning resources; (3) learning evaluation given by the teacher in accordance with predetermined learning objectives, namely regulating the character value of students, Assessing the ability to understand concepts, the value of student skills and attitude values in the learning process. Evaluations are carried out after each subject matter of the lesson.
\end{abstract}

\begin{abstract}
Abstrak: Penelitian ini bertujuan untuk mengetahui kompetensi pedagogik guru dalam pengelolaan pembelajaran dan kompetensi profesional guru dalam meningkatkan mutu pendidikan. Metode penelitian ini menggunakan penelitian deskriptif dengan pendekatan kualitatif. Teknik pengumpulan data dilakukan melalui wawancara, observasi, dan studi dokumentasi. Berdasarkan hasil penelitian disimpulkan bahwa kompetensi professional dan pengetahuan pedagogik guru menunjukkan (1) kompetensi yang dimiliki guru dalam merencanakan pembelajaran dalam menyusun RPP, penyusunan silabus, merencanakan media dan sumber pembelajaran serta merencanakan evaluasi pembelajaran sesuai dengan petunjuk yang ditetapkan, tetapi ada beberapa guru mengajar tidak membuat perencanaan pembelajaran; (2) strategi profesional guru dalam mengimplementasikan pembelajaran yaitu menguasai materi, struktur, dan konsep mata pelajaran yang diajarkan. Hal itu dilakukan dengan review materi sebelum melanjutkan, menyesuaikan materi dengan media/ sumber belajar; (3) evaluasi pembelajaran yang diberikan guru sesuai dengan tujuan pembelajaran yang telah ditetapkan, yaitu mencakup nilai karakter siswa, penilaian kemampuan memahami konsep, nilai keterampilan siswa dan nilai sikap dalam proses pembelajaran. Evaluasi dilakukan setiap selesai satu materi pokok bahasan pelajaran.
\end{abstract}

Dunia pendidikan menjadi salah satu pokok bahasan yang begitu luas dan kompleks. Salah satu lingkup pendidikan yaitu guru yang disebut sebagai tenaga pendidik merupakan komponen yang paling menentukan kualitas pendidikan karena ditangan gurulah kurikulum dikembangkan dan diaplikasikan. Di tangan guru yang profesional pembelajaran akan menjadi lebih bermakna. Sarana dan prasarana menjadi pendukung keterlaksanaannya pembelajaran. Pengalaman yang dibutuhkan guru untuk membentuk peserta didik menjadi insan yang berilmu, bertanggung jawab dan mampu menghadapi segala tantangan masa depan. Di samping itu, guru adalah pemeran utama dalam proses peningkatan kualitas pendidikan, khususnya pendidikan formal. Supriadi (1998) mengemukakan bahwa untuk menjadi profesional, seorang guru dituntut memiliki minimal lima hal, yaitu (1) mempunyai komitmen pada peserta didik dan proses belajarnya, (2) menguasai secara mendalam mata pelajaran yang diajarkan serta cara mengajarnya kepada peserta didik, (3) bertanggung jawab memantau hasil belajar peserta didik melalui 
berbagai cara evaluasi, (4) mampu berpikir sistematis tentang apa yang dilakukannya dan belajar dari pengalamannya, dan (5) seyogyanya merupakan bagian dari masyarakat belajar dalam lingkungan profesinya. Masterman \& Manton (2011) mengemukakan bahwa pemerintah memberikan apresiasi yang sangat tinggi terhadap profesionalitas guru yang selama ini diberi julukan pahlawan tanpa tanda jasa. Untuk dapat melaksanakan fungsinya dengan baik, guru wajib memiliki syarat tertentu, salah satunya yaitu kompetensi.

Kompetensi atau competency adalah kemampuan untuk melaksanakan suatu tugas/pekerjaan yang didasari atas pengetahuan, keterampilan dan sikap sesuai dengan unjuk kerja yang dipersyaratkan. Kompetensi guru merupakan kemampuan dan kewenangan seorang guru dalam melaksanakan kewajiban-kewajibannya secara bertanggungjawab terkait dengan profesi keguruannya. Karena jabatan guru merupakan pekerjaan profesi, maka kompetensi guru sangatlah dibutuhkan dalam proses belajar mengajar. Kompetensi pedagogik adalah keterampilan yang harus dimiliki guru dalam mengajarkan materi kepada siswa (Lidyasari, 2014). (Peraturan Pemerintah Republik Indonesia Nomor 19 Tahun 2005 tentang Standar Nasional Pendidikan, n.d.) Pasal 28 ayat 3 secara tegas dinyatakan: Ada empat kompetensi yang harus dimiliki guru. Keempat kompetensi itu adalah kompetensi pedagogik, kompetensi kepribadian, kompetensi professional dan kompetensi sosial. Dalam pendidikan anak, kinerja guru sangat diperlukan untuk mempersiapkan peserta didik melalui proses belajar mengajar. Undang-Undang Republik Indonesia Nomor 14 tahun 2005 Tentang Guru dan Dosen (2005) mengemukakan kompetensi pedagogik adalah kemampuan mengelola pembelajaran peserta didik. Depdiknas (2004) menyebut kompetensi ini dengan kompetensi pengelolaan pembelajaran. Kompetensi ini dapat ditinjau dari kemampuan untuk merencanakan program belajar-mengajar, kemampuan melaksanakan interaksi atau mengelola proses belajar-mengajar, dan kemampuan melakukan penilaian. Guru profesional adalah guru yang mampu mengelola dirinya sendiri dalam melaksanakan tugasnya sehari-hari. Profesionalisme yang dimaksud adalah satu proses yang bergerak dari ketidaktahuan menjadi tahu, dari ketidakmatangan menjadi matang (Wahyudi, 2012).

Berdasarkan pengamatan penulis tentang Kompetensi professional dan pengetahuan pedagogik guru di SDN Banyuajuh 2 Kamal dalam meningkatkan standar kompentensi guru itu sendiri. Kemampuan guru SD tersebut dalam pembelajaran tematik masih perlu ditingkatkan, terutama yang telah lulus sertifikasi ternyata kompetensinya belum maksimal, belum menunjukkan perbedaan kinerja yaitu guru kurang mampu menguasai teori belajar, masih banyak guru yang hanya mencopy dengan silabus dan rencana pembelajaran yang sudah ada sebelumnya dan tidak dikembangkan, dan guru-guru masih menggunakan proses pembelajaran pola lama, yaitu proses pembelajaran satu arah yang didominasi oleh guru yang tidak mengarahkan dan memfasilitasi peserta didik dalam belajar dan mengembangkan pembelajaran dari lingkungan dari mana peserta didik belajar. Metode pembelajaran yang digunakan kebanyakan hanya menggunakan metode ceramah dan masih banyak guru yang tidak menggunakan alat bantu dalam proses pembelajaran. Seharusnya guru yang professional dalam mengajar menggunakan metode dan media ataupun sumber yang beraneka ragam, sehingga peserta didik tidak merasa bosan dan cenderung pasif dalam kegiatan pembelajaran. Sebagian guru kurang memperhatikan prinsip-prinsip pembelajaran dalam menumbuhkan motivasi, minat, dan kreativitas siswa untuk belajar dan kurang berusaha untuk mengatasinya, guru kurang memperhatikan setiap siswa yang memiliki keberagaman individual, baik latar belakang kemampuan, pengetahuan, sikap, dan motivasi belajar siswa.

Pelaksanaan pembelajaran tematik di lapangan masih jauh dari yang diharapkan. Faktor utama tidak maksimalnya penerapan kurikulum 2013 adalah ada beberapa guru kurang pemahaman mendalam mengenai penerapan pembelajaran tematik yang ideal, seperti kesulitan dalam merancang silabus, RPP, melakukan penilaian, serta pengetahuan tentang model pembelajaran yang kurang memadai (Ruja \& Sukamto, 2015). Permasalahan-permasalahan penerapan kurikulum 2013 di sekolah, sejalan dengan hasil observasi dan wawancara di SDN Banyuajuh 2 Kamal. Hasil observasi ditunjang dengan hasil wawancara dengan guru yang menyatakan bahwa selalu melakukan pembelajaran di luar kelas. Guru juga menyatakan pendapatnya mengenai pembelajaran yang dilakukannya selama ini, dimana guru merasa siswa sangat pasif saat pembelajaran. Kurang aktifnya siswa dalam pembelajaran. Guru selama melakukan pembelajaran juga jarang menerapkan model pembelajaran yang inovatif karena guru merasa perlu waktu penyesuaian yang lama dalam menerapkan model pembelajarn inovatif. Pelaksanaan pembelajaran yang dilakukan guru selama ini dapat dikatakan masih berpusat pada siswa dan monoton. Fasilitas pembelajaran di SDN Banyuajuh 2 Kamal yang digunakan tidak dikembangkan, yaitu hanya berupa buku guru, buku siswa, dan menggunakan media yang sudah ada.

Uraian hasil wawancara dan observasi menunjukkan adanya masalah yang berkaitan dengan rendahnya kompetensi guru selama proses pembelajaran. Penyebab utama rendahnya kompetensi guru pada pembelajaran berkaitan dengan pembelajaran yang monoton, membosankan, dan berpusat pada guru. Pembelajaran yang dilakukan di kelas hendaknya diterapkan dengan model pembelajaran yang melibatkan siswa aktif membangun pengetahuannya secara mandiri. Metode pembelajaran yang digunakan kebanyakan hanya menggunakan metode ceramah dan tidak menggunakan alat bantu dalam proses pembelajaran. Seharusnya guru yang telah memiliki sertifikat pendidik dalam mengajar banyak menggunakan metode dan media ataupun sumber yang beraneka ragam sehingga peserta didik tidak merasa bosan dan cenderung pasif dalam kegiatan pembelajaran. Sebagian guru kurang memperhatikan prinsip-prinsip pembelajaran dalam menumbuhkan motivasi, minat, dan kreativitas siswa untuk belajar dan kurang berusaha untuk mengatasinya, guru kurang memperhatikan setiap siswa yang memiliki keberagaman individual, baik latar belakang kemampuan, pengetahuan, sikap dan motivasi belajar siswa. Pendekatan pembelajarannya menggunakan pendekatan konsep. 
Penelitian yang telah dilakukan oleh Rahayu, Susilowati, \& Rahayu (2012) tentang kompetensi pedagogik dan kepribadian guru Biologi bersertifikasi pendidik di SMA 3 Semarang bahwa kompetensi pedagogik guru dalam pengelolaan pembelajaran cukup baik, tetapi belum optimal dalam mengaplikasikan pengelolaan pembelajaran yang memenuhi standar sains. Proses pembelajaran peserta didik hanya menerima konsep yang diberikan oleh guru tanpa pernah membuktikan konsep tersebut. Penelitian sebelumnya juga telah dilakukan oleh Fitriani, Murniati, \& Usman (2017) yang melakukan penelitian tentang kompetensi professional guru dalam pengelolaan pembelajaran di MTs muhammadiyah banda Aceh bahwa kompetensi professional dalam pengelolaan pembelajaran cukup baik, tetapi ada beberapa guru mengajar tidak membuat perencanaan pembelajaran.

Paparan latar belakang masalah menjadi dasar penelitian dengan menyatukan kompetensi profesional dengan kompetensi pedagogik. Hal tersebut juga menjadi pembeda penelitian ini dibandingkan penelitian-penelitian yang telah dilakukan sebelumnya. Berdasarkan latar belakang masalah, maka penelitian tindakan ini bertujuan untuk mengetahui permasalahan yaitu bagaimana kompetensi profesional dan kompetensi pedagogik guru dalam pengelolaan pembelajaran sekolah dasar?

\section{METODE}

Penelitian ini dilakukan dengan menggunakan jenis penelitian studi kasus dengan pendekatan kualitatif. Umar (2012) mengemukakan bahwa keberhasilan penelitian deskriptif kualitatif sangat ditentukan oleh ketelitian, kelengkapan catatan lapangan (field note) yang disusun peneliti dari hasil observasi, serta wawancara secara mendalam. Penelitian ini dilakukan melalui empat tahapan, yaitu pra lapangan, lapangan, analisis data dan penulisan. Pada tahap pra lapangan dilakukan menentukan judul penelitian berdasarkan data hasil observasi dan wawancara awal, maka ditentukan bahwa. Subjek penelitian ini adalah Guru SDN Banyuajuh 2 Kamal yang berjumlah tiga orang, terdiri dari guru kelas V, guru kelas VI, dan Kepala Sekolah.

Teknik pengumpulan data dalam penelitian kualitatif menggunakan beberapa teknik, yaitu melalui observasi, wawancara, dan dokumentasi. Ketiga metode pengumpulan data tersebut diharapkan dapat saling melengkapi sehingga diperoleh suatu informasi yang diharapkan. Adapun teknik analisis data yang digunakan dalam penelitian ini sebagaimana yang dikemukakan oleh Miles \& Huberman (1984) dilakukan dengan teknik analisis data deskriptif kualitatif yang dilakukan dalam tiga tahap, yaitu kondensasi data, penyajian data, dan penarikan kesimpulan. Kondensasi data dilakukan pada hasil data observasi guru dimana data yang tidak mendukung akan dikondensasi dan dipilih sesuai dengan rumusan masalah ataupun tujuan penelitian yang ditetapkan. Penyajian data pada penelitian ini adalah dalam bentuk deskripsi, narasi, dan argumentasi. Setelah dilakukan dua tahap tersebut, maka merumuskan kesimpulan mengenai kompetensi professional dan pedagogik guru dalam pengelolaan pembelajaran di sekolah dasar. Penafsiran terhadap hasil analisis data didasarkan atas indikator kompetensi guru (Simola, 1997).

\section{HASIL}

Berdasarkan temuan yang diperoleh di lapangan, SDN Banyuajuh 2 Kamal, sebelum memulai proses pembelajaran, maka guru mempersiapkan perencanaan dengan menyusun rencana pembelajaran yang sesuai dengan mata pelajaran yang diampu. Silabus sebagai acuan dalam pengembangan Rencana Pelaksanaan Pembelajaran yang memuat identitas mata pelajaran atau tema pelajaran, standar kompetensi, kompetensi dasar, materi pembelajaran, kegiatan pembelajaran, indikator pencapaian kompetensi, penilaian, alokasi waktu dan sumber belajar. Hal ini sesuai dengan pendapat Terry dalam (Zulkifli, 2014) bahwa perencanaan adalah memilih dan menghubungkan fakta-fakta dan membuat serta menggunakan asumsi-asumsi mengenai masa yang akan datang dengan cara menggambarkan dan merumuskan kegiatan-kegiatan yang diperlukan untuk mencapai hasil yang diinginkan. Berdasarkan penjelasan di atas bahwa perencanaan merupakan suatu indikator yang sangat penting dalam pembelajaran di sekolah untuk tercapainya suatu tujuan pembelajaran. Setiap pembelajaran yang diawali dengan kegiatan perencanaan yang sistematis dan terarah yang dikemas dalam bentuk Rencana Pelaksanaan Pembelajaran.

Dengan perencanaan yang baik dan sistematis guru dapat menyiapkan dirinya dalam segala perangkat pembelajaran yang telah ditentukan sehingga proses pembelajaran di sekolah berjalan dengan yang diharapkan. Dalam pelaksanaannya Guru di SDN Banyuajuh 2 Kamal menyiapkan perencanaan pembelajaran sebelum melaksanakan proses pembelajaran. Perencanaan pembelajaran yang disiapkan oleh guru di SDN Banyuajuh 2 Kamal dibuat sebelum mulai tahun ajaran baru (sesudah kenaikan kelas), tetapi masih ada guru yang tidak mengembangkan perangkat pembelajaran tersebut.

Dalam mengembangkan bahan ajar tersebut dibutuhkan kemampuan penguasaan kompetensi pedagogik dan professional oleh guru agar menjalani aktivitas mengajarnya dengan lebih baik, penggunaan metode pembelajaran yang lebih variatif, penggunaan model pembelajaran yang baik, pemanfaatan media pembelajaran yang sesuai, pengelolaan penilaian yang objektif. Kompetensi professional dan pedagogik selayaknya dimiliki oleh guru. Berikut adalah indikator dari kompetensi profesional dan kompetensi pedagogik disajikan pada tabel 1. 
Tabel 1. Kompetensi professional dan pedagogik

\begin{tabular}{clll}
\hline \multicolumn{1}{c}{ Aspek-Aspek } & Karakteristik & & \multicolumn{1}{c}{ Indikator } \\
\hline Kinerja Guru & Profesional & 1. & Penguasaan materi, struktur, konsep, dan pola fikir keilmuan \\
& & yang mendukung mata pelajaran yang diampu \\
& 2. & Mengembangkan keprofesian melalui tindakan reflektif \\
\cline { 2 - 4 } & Pedagogik & 1. & Memahami kurikulum pembelajaran \\
& 2. & Menyusun perencanaan dan tujuan pembelajaran \\
& 3. & Penggunaan strategi dan metode pembelajaran \\
& 4. & Menggunakan media pembelajaran \\
& 5. & Ketepatan waktu menyampaikan materi \\
& 6. & Melakukan pembelajaran remidial \\
& 7. & Melakukan evaluasi pembelajaran \\
\hline
\end{tabular}

\section{PEMBAHASAN}

Berdasarkan temuan yang diperoleh dari lapangan terhadap kompetensi professional dan pedagogik guru menunjukkan bahwa kompetensi professional dan pedagogik guru di SDN Banyuajuh 2 Kamal berbeda-beda. Perbedaan kompetensi guru tersebut bisa dilihat latar belakang dan pengalaman mengajar guru. Sebagai contoh guru yang mengajarnya sudah lama belum tentu memiliki kompetensi pedagogik yang bagus, guru yang masih muda belum tentu kompetensinya rendah, guru yang sudah sertifikasi belum tentu mempunyai kompetensi pedagogik yang bagus pula. Kemudian latar belakang pengalaman juga memengaruhi kompetensi pedagogik guru. Djamarah (2000) menjelaskan bahwa perbedaan latar belakang pendidikan akan memengaruhi kegiatan guru dalam melaksanakan interaksi pembelajaran di kelas. Latar belakang dan pengalaman mengajar guru berpengaruh terhadap pelaksanaan pembelajaran dikelas karena dalam pembelajaran melibatkan kompetensi pedagogik dan kompetensi professional dari guru tersebut.

Dari hasil observasi pada pengelolaan pembelajaran di kelas yang terkait dengan proses pembelajaran, guru melaksanakan pembelajaran antara lain dalam hal perencanaan pembelajaran. Perencanaan dituangkan dalam bentuk Rancangan Pelaksanaan Pembelajaran (RPP). RPP yang digunakan di SDN Banyuajuh 2 Kamal merupakan RPP dari Kabupaten yang di distribusikan melalui kegiatan KKG. RPP tersebut mencakup RPP tematik sesuai dengan K-13. Mengenai RPP yang sudah ada tersebut, guru yang mempunyai kompetensi pedagogik dalam hal perencanaan pembelajaran bagus maka cenderung akan mengembangkan RPP tersebut sesuai dengan situasi dan kondisi siswa. Sementara guru yang memiliki kompetensi rendah dalam hal RPP maka akan cenderung melakukan pembelajaran sesuai dengan yang ada pada RPP tanpa mengembangkan dan menganalisis terlebih dahulu. Temuan lain pada proses/pelaksanaan pembelajaran di SDN Banyuajuh 2 Kamal, yaitu mengenai pembelajaran yang disampaikan oleh guru kelas V dan guru kelas VI. Dalam mengemas pembelajaran diantaranya guru yang kompetensi dan profesionalnya bagus cenderung mengembangkan pembelajaran sesuai dengan karakteristik siswa dan kebutuhan siswa. Hal tersebut terlihat pada pembelajaran di kelas VI. Kreativitas guru dalam mengembangkan media pembelajaran, model pembelajaran dan menggunakan berbagai sumber untuk belajar merupakan bagian dari peran guru dalam hal pelaksanaan pembelajaran di kelasnya. Hal tersebut sesuai dengan yang disampaikan oleh Widyastono (2014) menjelaskan bahwa kegiatan inti menggunakan metode yang disesuaikan dengan karakteristik peserta didik dan mata pelajaran. Metode tersebut menjadi tahapan yang akan membantu guru dalam melaksanakan pembelajaran tematik di kelas.

Metode yang sesuai dengan materi pembelajaran akan memudahkan siswa dalam menyerap pengetahuan maupun memancing siswa dalam menemukan konsep materi pembelajaran. Hal sebaliknya terjadi di kelas V. Pembelajaran yang dilakukan kebanyakan menggunakan metode yang konvensional serta mengemas pembelajaran tidak terlihat. Cara pengemasan pengalaman belajar yang dirancang guru sangat berpengaruh terhadap kebermaknaan belajar siswa. Pengalaman belajar yang mengaitkan unsur-unsur konseptual menjadikan proses pembelajaran yang lebih efektif dan tida monoton. Pada proses penilaian pembelajaran ditemukan bahwa guru tidak selalu melakukan penilaian yang sesuai dengan tuntutan K-13. Penilaian yang dilakukan cenderung hanya mengukur kognitif siswa saja. Guru yang tingkat kompetensi pedagogik dan kompetensi professional dalam hal penilaian rendah cenderung mengabaikan penilaian sesuai dengan tuntutan K-13, sedangkan guru yang tingkat kompetensi professional dan kompetensi pedagogiknya tinggi dalam hal penilaian cenderung berusaha melaksanakan penilaian sesuai dengan yang dianjurkan.

Paparan hasil analisis data demi mewujudkan pembelajaran untuk meningkatkan kompetensi penguasaan materi pembelajaran secara luas dan mendalam. (Hamalik, 2008) menyatakan bahwa kompetensi profesional yaitu kemampuan guru dalam mengarahkan kegiatan belajar mengajar bagi peserta didik untuk mencapai tujuan pembelajaran, untuk itu guru dituntut mampu menguasai materi pelajaran dengan baik. Guru harus meng-update materi pelajaran yang disajikan dengan cara mempersiapkan diri dengan materi pelajaran yang akan disajikan dan diusahakan dengan mencari informasi melalui berbagai sumber seperti membaca buku-buku terbaru, mengakses dari internet, selalu mengikuti perkembangan dan kemajuan tentang materi yang disajikan. Hasil penelitian pada indikator mengembangkan profesional melalui tindakan reflektif baik dan cukup baik disebabkan karena sebagian responden tidak melakukan evaluasi diri untuk mengetahui keberhasilan dari suatu materi pelajaran, mengikuti pelatihan atau diklat sudah sangat jarang diikuti oleh guru untuk menambah pengetahuan. 
Hal ini relevan dengan Isjoni (2006) mengemukakan bahwa pengembangan profesional guru harus diakui sebagai suatu hal yang sangat fundamental dan penting guna meningkatkan mutu pendidikan. Pengembangan profesional adalah proses dimana guru meningkatkan dan menggunakan pengetahuan, keterampilan dan nilai secara tepat. Peningkatan kompetensi guru dapat dilakukan melalui program pelatihan. Pelatihan mengandung arti untuk terdorong motivasinya dalam memperbaiki kinerjanya, serta cara pembelajaran. Pelatihan secara umum diartikan sebagai kegiatan untuk memperbaiki penguasaan berbagai keterampilan dan teknik pelaksanaan kerja tertentu dalam waktu yang singkat (Sikula, 1976). Pengembangan diri yang optimal, membuat guru merasa tidak akan tampil lagi sebagai pengajar (teacher), seperti fungsinya yang menonjol selama ini, tetapi beralih sebagai pelatih (coach) dan manajer belajar (learning manager), sebagai pelatih seorang guru akan mendorong peserta didik untuk menguasai alat belajar, memotivasi peserta didik untuk bekerja keras dan mencapai prestasi yang setinggi-tingginya, sebagai manajer belajar, guru akan membimbing peserta didik, mengambil prakarsa, dan mengeluarkan ide-ide yang dimilikinya.

Kompetensi guru dalam pembelajaran tematik merupakan faktor penentu yang sangat dominan dalam pendidikan pada umumnya, karena guru memegang peranan dalam proses pembelajaran, dimana proses pembelajaran merupakan inti dari proses pendidikan secara keseluruhan yang melibatkan aspek kompetensi guru tersebut (Khofiatun, Akbar, \& Ramli, 2016). Tuntutan memiliki kompetensi yang bagus mendorong guru untuk memperoleh informasi yang dapat memperkaya kemampuan agar tidak mengalami ketinggalan. Kompetensi guru bersifat menyeluruh dan merupakan satu kesatuan yang saling berhubungan dan saling mendukung antara satu dengan yang lain, tetapi dalam proses pembelajaran, kompetensi pedagogik dan kompetensi profesional mempunyai peranan yang sangat penting karena berhubungan langsung dengan tugas pokok seorang guru, yakni sebagai pengelola proses pembelajaran.

\section{SIMPULAN}

Berdasarkan hasil penelitian dan pembahasan tentang kompetensi pedagogik dan profesional guru SD maka peneliti dapat menarik kesimpulan sebagai berikut. Pertama, kompetensi pedagogik guru SD cukup baik. Dari tujuh indikator kompetensi pedagogik, indikator penilaian dan evaluasi belum optimal disebabkan karena guru dalam melakukan penilaian selalu pada akhir pembelajaran yang hanya melihat pada hasil bukan pada proses, penilaian selalu dalam bentuk tes tertulis dan guru tidak melakukan analisis penilaian pada tiap SK/KD. Kompetensi yang dimiliki guru dalam perencanaan pembelajaran khususnya dalam menyusun RPP sudah cukup baik, mereka menyusun RPP sesuai dengan petunjuk yang ditetapkan. Hal itu dapat dilihat pada membuat perangkat pembelajaran (RPP), pengalokasian waktu, mencantumkan sumber belajar yang akan digunakan, akan tetapi ada beberapa guru pada SDN Banyuajuh 2 Kamal yang tetap mengajar, walau tanpa membuat perencanaan pembelajaran (RPP).

Kedua, kompetensi profesional guru SD cukup baik. Dari dua indikator kompetensi profesional kemampuan guru belum optimal, disebabkan dalam menyajikan materi peserta didik hanya menerima apa yang diberikan, tanpa melalui pengamatan, analisis, praktik, dan menyimpulkan. Dalam pengembangan profesional guru belum optimal dalam melakukan evaluasi diri, memiliki jurnal pembelajaran dan mengikuti pelatihan/diklat. Strategi profesional guru dalam mengimplementasikan pembelajaran ternyata sudah mengikuti prosedur pelaksanaan yang ditetapkan dan sesuai dengan kurikulum yang berlaku. Hal itu dilakukan dengan melakukan review materi sebelum melanjutkan, menyesuaikan materi dengan media/sumber belajar, tetapi masih ada juga guru yang kurang dalam penguatan pengimplementasian pembelajaran dan saat menutup pembelajaran guru tidak menyuruh siswa merefleksikan materi pembelajaran yang telah diajarkan, serta tidak menggunakan media/sumber belajar yang tepat. Evaluasi pembelajaran yang dilaksanakan oleh guru dalam meningkatkan mutu pendidikan juga sudah baik, dimana para guru melakukan evaluasi setiap setelah melakukan pembahasan pembelajaran. Penilaian guru terhadap evaluasi yang diberikan kepada siswa dengan rentang waktu yang berbeda, akan tetapi ada beberapa guru yang memberikan nilai tidak objektif sesuai dengan kemampuan siswa.

Berdasarkan hasil penelitian dan kesimpulan, peneliti dapat mengemukakan saran-saran sebagai berikut. Pertama, kompetensi pedagogik harus dikuasai oleh semua guru dan diharapkan agar guru lebih berperan dalam proses pembelajaran di kelasnya serta menerapkan aturan yang berlaku dalam pembelajaran tematik sesuai tuntutan kurikulum. Kedua, bagi peneliti lain diharapkan dapat melakukan penelitian lebih jauh tentang kompetensi professional dan kompetensi pedagogik guru dalam pengelolaan pmbelajaran.

\section{DAFTAR RUJUKAN}

Depdiknas. (2004). Peningkatan Kinerja Kepala Sekolah. Jakarta: Direktorat Jendral Pendidikan Dasar dan Menengah. Direktorat Pendidikan Sekolah Menengah Atas.

Djamarah, S. B. (2000). Guru dan Anak Didik Dalam interaktif Edukatif. Jakarta: Rineka Cipta.

Fitriani, C., Murniati, A. R., \& Usman, N. (2017). Kompetensi Profesional Guru Dalam Pengelolaan. Jurnal Administrasi Pendidikan Program Pascasarjana Unsyiah, 5(2), 88-95.

Hamalik, O. (2008). Proses Belajar Mengajar. Jakarta: PT. Bumi Aksara.

Isjoni. (2006). Gurukah yang Dipersalahkan? Yogyakarta: Pustaka Pelajar.

Khofiatun., Akbar, S., \& Ramli, M. (2016). Peran Kompetensi Pedagogik Guru Dalam Pembelajaran Tematik di Sekolah Dasar. Jurnal Pendidikan: Teori, Penelitian, dan Pengembangan, 1(5), 984-988. 
Lidyasari, A. T. (2014). Developing PGSD Students Character through Experience Learning Theory. Procedia - Social and Behavioral Sciences. https://doi.org/10.1016/j.sbspro.2014.01.1414

Masterman, E., \& Manton, M. (2011). Teachers' Perspectives on Digital Tools for Pedagogic Planning and Design. Teachers' Perspectives on Digital Tools for Pedagogic Planning and Design, 20(2), 227-246. https://doi.org/10.1080/1475939X.2011.588414

Miles, M. B., \& Huberman, A. M. (1984). Qualitative Data Analysis. Baverly Hill: Sage Publication Inc.

Rahayu, G. P., Susilowati, S. M. E., \& Rahayu, E. S. (2012). Kompetensi Pedagogik dan Kepribadian Guru Biologi Bersertifikat Pendidik di SMA 3 Semarang. Journal of Biology Education, 1(2), 51-58.

Ruja, I. N., \& Sukamto. (2015). Survey Permasalahan Implementasi Kurikulum Nasional 2013 Mata Pelajaran Ilmu Pengetahuan Sosial Sekolah Menengah Pertama di Jawa Timur. Jurnal Sejarah dan Budaya, 9(2), 193-199.

Sikula, A. E. (1976). Personnel Administration and Human Resources Management. Santa Barbara: John Wiley \& Sons.

Supriadi, D. (1998). Mengangkat Citra dan Martabat Guru. Yogyakarta: Adicita Karya Nusantara.

Umar, M. (2012). Kompetensi Profesional Dosen: Upaya Pengembangan Profesional Tenaga Pengajar Fakultas Syari'ah IAIN Ar-Raniry Banda Aceh.

Undang-Undang Republik Indonesia Nomor 14 tahun 2005 Tentang Guru dan Dosen. (2005).

Wahyudi, I. (2012). Pengembangan Pendidikan, Strategi Inovatif \& Kreatif Dalam Mengelola Pendidikan Secara Konprehensif. Jakarta: PT. Prestasi.

Widyastono, H. (2014). Pengembangan Kurikulum di Era Otonomi Daerah dari Kurikulum 2004, 2006, ke Kurikulum 2013. Jakarta: Bumi Aksara.

Zulkifli. (2014). Strategi Kepala Sekolah Dalam Meningkatkan Kompetensi Profesional Guru pada SMA Negeri 1 Peukan Bada Kabupaten Aceh Besar. Jurnal Ilmiah Didaktika: Media Ilmiah Pendidikan dan Pengajaran, 14(2), 305-319. http://dx.doi.org/10.22373/jid.v14i2.505 